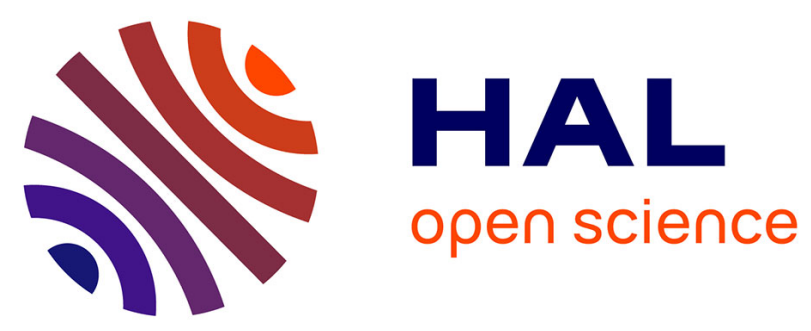

\title{
Different flowering response to various fruit loads in apple cultivars correlates with degree of transcript reaccumulation of a TFL1-encoding gene
}

Amnon Haberman, Michal Ackerman, Omer Crane, Jean-Jacques Kelner, Evelyne E. Costes, Alon Samach

\section{To cite this version:}

Amnon Haberman, Michal Ackerman, Omer Crane, Jean-Jacques Kelner, Evelyne E. Costes, et al.. Different flowering response to various fruit loads in apple cultivars correlates with degree of transcript reaccumulation of a TFL1-encoding gene. Plant Journal, 2016, 87 (2), pp.161-173. 10.1111/tpj.13190 . hal-02635987

\section{HAL Id: hal-02635987 \\ https://hal.inrae.fr/hal-02635987}

Submitted on 27 May 2020

HAL is a multi-disciplinary open access archive for the deposit and dissemination of scientific research documents, whether they are published or not. The documents may come from teaching and research institutions in France or abroad, or from public or private research centers.
L'archive ouverte pluridisciplinaire HAL, est destinée au dépôt et à la diffusion de documents scientifiques de niveau recherche, publiés ou non, émanant des établissements d'enseignement et de recherche français ou étrangers, des laboratoires publics ou privés. 
Received Date : 10-Aug-2015

Revised Date : 04-Apr-2016

Accepted Date : 05-Apr-2016

Article type : Original Article

Full Title: Different flowering response to various fruit loads in apple cultivars correlates with degree of transcript reaccumulation of a TFL1-encoding gene

Amnon Haberman ${ }^{1}$, Michal Ackerman ${ }^{1}$, Omer Crane ${ }^{2}$, Jean-Jacques Kelner ${ }^{3}$, Evelyne Costes ${ }^{3}$ and Alon Samach ${ }^{1 *}$

${ }^{1}$ The Robert H. Smith Institute of Plant Sciences and Genetics in Agriculture, Faculty of Agriculture, Food and Environment, The Hebrew University of Jerusalem, Rehovot, Israel.

${ }^{2}$ Migal-Galilee Technological Center, Kiryat Shmona, Israel.

${ }^{3}$ INRA, UMR AGAP, AFEF team (Architecture and functioning of fruit species), Montpellier,

France.

Corresponding author: Alon Samach, The Robert H. Smith Institute of Plant Sciences and Genetics in Agriculture, Faculty of Agriculture, Food and Environment, The Hebrew University of Jerusalem, P.O. Box 12, Rehovot 76100, Israel. Tel: 00972-8-9489812, Fax: 00972-8-9489899, E-mail: alon.samach@mail.huji.ac.il

This article has been accepted for publication and undergone full peer review but has not been through the copyediting, typesetting, pagination and proofreading process which may lead to differences between this version and the Version of Record. Please cite this article as an 'Accepted Article', doi: 10.1111/tpj.13190

This article is protected by copyright. All rights reserved. 
Running title: Alternate bearing in apple

Keywords: flowering, Malus domestica, alternate bearing, genetic variation, TERMINAL FLOWER 1, fruit load.

\section{Summary}

In many perennial fruit trees, flowering in the year following a year with heavy fruit load can be quite limited. This biennial cycle of fruiting, termed alternate bearing, was described 170 years ago in apple (Malus domestica). Apple inflorescences are mainly found on short branches (spurs). Bourse shoots (BS) develop from the leaf axils of the spur. BS apices may terminate $\sim 100$ days after flowering, with formation of next year's inflorescences. We sought to determine how developing fruit on the spur prevent the adjacent BS apex from forming an inflorescence. The presence of adjacent fruit correlated with reaccumulation of transcript encoding a potential flowering inhibitor, MdTFL1-2, in BS apices prior to inflorescence initiation. BS apices without adjacent fruit that did not flower due to late fruitlet removal, neighboring fruit on the tree, or leaf removal, also reaccumulated MdTFL1-2 transcript. Fruit load and gibberellin (GA) application had similar effects on the expression of MdTFL1-2 and genes involved in GA biosynthesis and metabolism. Some apple cultivars are less prone to alternate bearing. We show that the response of a BS apex to different numbers of adjacent fruit differs among cultivars in both MdTFL1-2 accumulation and return flowering. These results provide a working model for the further study of alternate bearing, and help clarify the need for cultivar-specific approaches to reach stable fruit production.

This article is protected by copyright. All rights reserved. 


\section{INTRODUCTION}

In many plants, environmental cues perceived by leaves promote a flowering response termed 'flower induction'. The output is a mobile signal, termed 'Florigen', traveling from the leaf to the apical meristem and changing the latter's fate from leaf to inflorescence formation (Lang et al., 1977). A protein component of this signal is termed FLOWERING LOCUS T (FT) in Arabidopsis thaliana (Kardailsky et al., 1999; Kobayashi et al., 1999; Corbesier et al., 2007; Tamaki et al., 2007). A similar protein with an opposite function, named CENTRORADIALIS in Antirrhinum majus (Bradley et al., 1996) and TERMINAL FLOWER1 (TFL1) in Arabidopsis (Shannon and Meeks-Wagner, 1991; Bradley et al., 1997), seems to maintain indeterminacy of the inflorescence meristem as well as delay the floral transition in Arabidopsis. Abnormally high levels of FT or reduced function/levels of TFL1 cause the inflorescence meristem to transform quite rapidly into a flower primordium, thus terminating the meristem. The function of TFL1-like proteins has been shown to be important in many other annuals (Tamaki et al., 2007; Putterill et al., 2013) and perennials (Lifschitz et al., 2006; Hsu et al., 2011; Freiman et al., 2012; Iwata et al., 2012; Koskela et al., 2012; Higuchi et al., 2013).

The apple genome contains two FT and two TFL1-encoding genes (Mimida et al., 2009; Kotoda et al., 2010). Transgenic knockdown of TFL1-encoding genes results in precocious flowering (no juvenile phase), terminal single flowers and continuous flowering during the year (Kotoda et al., 2006; Sasaki et al., 2011; Flachowsky et al., 2012). Ectopic overexpression of MdFT1 (Kotoda et al., 2010), MdFT2 (Traekner et al., 2010) or Arabidopsis FT (Yamagishi et al., 2011) in apple also causes precocious flowering.

This article is protected by copyright.All rights reserved. 
Perennials that flower once a year require a mechanism to time flower induction and initiation to a specific season (Bergonzi and Albani, 2011; Samach and Smith, 2013). In some cases, inductive environmental cues may act through an increase in FT, such as in mango (Mangifera indica; Nakagawa et al., 2012), or through a reduction in TFL1 as shown in rose (Iwata et al., 2012) and strawberry (Fragaria vesca; Koskela et al., 2012). In apple, the formation of inflorescence meristems occurs approximately 100 days after full bloom (DAFB) (Foster et al., 2003). Following anthesis, expression of one of the TFL1-encoding genes, MdTFL1-1, decreases within the apices, plateauing well before initiation of the following year's flowers (Hattasch et al., 2008; Mimida et al., 2009, 2011; Kotoda et al., 2010).

In many perennial fruit trees, flowering is quite limited after a year with heavy fruit load (HFL), while flowering is abundant after a year with few fruit (Monselise and Goldschmidt, 1982; Smith and Samach, 2013). This biennial cycle of fruiting, termed 'alternate bearing', is often detrimental in commercial orchards because fruit size in HFL can be below commercial standards. Without farmer intervention (thinning of HFL trees), most apple cultivars eventually enter this cycle of flowering and fruiting (Durand et al., 2013; Figure 1a,b). Among many other traits, apple breeders try to select for cultivars with cycles of lower amplitude (Guitton et al., 2012; Durand et al., 2013).

An apple inflorescence contains 4-6 flowers; the number of fruitlets reaching maturity within an inflorescence depends, among other things, on pollination and genotype (Eccher et al., 2013; Celton et al., 2014). Fruit of important cultivars develop mostly on inflorescences formed on spurs (Butler, 1917; Forshey and Elfving, 1989). Spurs are short branches (having limited internode elongation) formed during 2 or more years of sympodial growth (Smith and Samach, 2013). Dormant inflorescence-containing spur buds are released in the spring. After anthesis, one or two shoots (termed 'bourse shoots'; BS) develop from 
lateral meristems formed the previous summer in the axils of the first expanded leaves, below the terminal inflorescence (Mehri and Crabbe, 2002; Figure 1c-e). BS contain a few expanded leaves separated by short internodes, followed by bud scales and leaf primordia (first leaves of the following year's flush), and will either terminate with an inflorescence or remain vegetative. The number of primordia formed below the terminal flower is relatively uniform (16-21), with slight differences between genotypes (McLaughlin and Greene, 1991; Costes, 2003). Together with a set plastochron (Fulford, 1966), the time between anthesis and initiation of the following year's inflorescence seems to be programmed and less influenced by the environment (Wilkie et al., 2008). Nevertheless, the presence of developing fruit adjacent to BS severely inhibits inflorescence formation (Figure S1). When most spurs on a tree contain developing fruit, this will lead to alternate bearing (Auchter and Schrader, 1923; Jonkers, 1979). In annuals such as Arabidopsis, although time to floral transition can be delayed or hastened, it eventually occurs. In apple, time of inflorescence initiation (TII) is defined more or less by DAFB, but the decision every year is binary: some meristems will go through the transition while others will not.

Here, our aim was to reveal how fruit load interferes with the molecular events leading to inflorescence formation in apple, and whether these events vary with genotype. We report that the presence of adjacent fruit leads to the reaccumulation in BS apices of transcript encoding MdTFL1-2, a flowering repressor. Variations in alternate bearing amplitude among cultivars correspond to differences in MdTFL1-2 reaccumulation. Taken together, our results provide a working model for the further study of alternate bearing, and suggests points of intervention in apple breeding and management.

This article is protected by copyright. All rights reserved. 


\section{RESULTS}

\section{Apple inflorescence initiation in response to different levels of crop load}

In the spring, heavy-flowering cultivar 'Top Red' trees (Figure 1a) were selected in an experimental orchard and all flowers were removed at full bloom (complete flower/fruitlet removal, designated CFR at 0 DAFB). The following spring, released buds were recorded on the spurs of those trees and close to $100 \%$ contained inflorescences (Figure 2a). Flower initiation was also followed in samples of BS apices from those trees during the summer by scanning electron microscopy (SEM; Figures 3 and S2). Initially, the relatively flat meristem produced leaf primordia (Figure 3a). The first noticeable change in the apical meristem occurred when no new leaf primordia formed, causing its enlargement and bulging (doming, Figures $3 \mathrm{~b}$ and $\mathrm{S} 2 \mathrm{a}-\mathrm{c})$. Later stages of inflorescence development are shown in Figures $3 \mathrm{c}$ and $\mathrm{S} 2 \mathrm{~d}-1$. In the summer, doming meristems were identified at 98-113 DAFB. The timing of these events, relative to day of full bloom, was similar to that described for 'Royal Gala' in New Zealand (Foster et al., 2003), with slight differences in morphology or its interpretation (Figure S2).

The level of transcript encoding the regulator of flower meristem identity APETALA1 (MdAP1a, MdAPlb; Mimida et al., 2011) and the regulator of flower organ identity PISTILLATA (MdPI; Yao et al., 2001) increased in BS apices taken from CFR at 0 DAFB trees (Figure $4 \mathrm{a}-\mathrm{f}$ ). This increase occurred during the period of inflorescence formation (based on SEM monitoring; Figures 3 and S2). Thus, BS apices of 'Top Red' begin forming inflorescences under local conditions at 94-100 DAFB.

This article is protected by copyright. All rights reserved. 
The fate of BS apices, specifically those subtending a spur with at least two fruit reaching commercial harvest, was measured in trees with heavy flowering and no fruit thinning, and thus with HFL. Here, the percentage of BS that formed inflorescences reaching anthesis the following spring was 0 (Figure 2a). A tree that was previously under HFL still formed several inflorescences the following year (Figures $1 \mathrm{~b}$ and S3a), likely on spurs that developed no fruit. When studying SEM micrographs from random BS taken from HFL trees at the end of the summer, most remained vegetative (Figure 3d). BS apices randomly collected from HFL trees expressed much lower levels of $M d A P 1 a, M d A P 1 b$ and $M d P I$ transcript when their expression was increasing in BS apices of trees with no fruit (Figure 4af).

For a limited period, young fruitlet removal allows return bloom on the branch (Harley et al., 1935). To determine the time at which the fate of the BS apex is influenced by HFL, the last day on which CFR could still lead to a heavy return bloom was roughly determined. In addition to CFR at 0 DAFB, heavy blooming trees in 2013 were subjected to CFR at a later date, 36 or $80 \mathrm{DAFB}$, and return bloom was measured the following spring (Figures 2a and S3a). The fate of BS apices was not set before 36 DAFB, since CFR on this date completely reversed the fate of their meristems: almost all (96\%) of the BS had a return bloom (Figure 2a). In contrast, CFR at 80 DAFB only partially reversed the fate of the meristems (Figure 2a). This suggests that at least some irreversible events that determine meristem fate occurred before this time.

\section{Expression of FT-encoding genes is not affected by fruit load}

In several species, an increase in FT-encoding transcript in leaves is associated with flower induction, an event preceding inflorescence initiation (Andres and Coupland, 2012). If this event can be detected in apples, does a similar event occur in trees under HFL? The 
expression of two genes encoding proteins similar to FT, MdFT1 and MdFT2, was determined in three different tissues (see Experimental Procedures): two types of leaves, and BS apices (Figure 1c-e); and under two different regimes of fruit load: HFL and CFR on 0 DAFB. For both genes, in both treatments, highest expression was detected in developing BS apices and not in leaves (Figures S4a,b and S5a,b). In BS apices, expression of MdFT1 increased gradually and substantially with time in trees with or without fruit, peaking $68-83$ DAFB (Figure S4c). The rise in MdFT2 expression in BS occurred only on the last sampling date, 126 DAFB, in trees with or without fruit, in both years tested (Figure S5c,f). Neither gene's expression increased significantly in the leaves during the measurement period (Figures S4d,e and S5d,e). An event in the leaves preceding TII could therefore not be defined, and a clear effect of fruit load was not detected on the expression of either FTencoding gene. Thus, additional markers were sought.

\section{Reduction in MdTFL1-1 expression in BS apices prior to flower initiation}

Expression of the two genes encoding TFL1 in apple was studied. In trees in which all fruit had been removed, MdTFL1-1 was predominantly expressed in BS apices (Figure S6a). The highest expression levels were measured near bloom, followed by a steep decrease with time, plateauing at 68 DAFB (Figure 4g), as shown previously (Mimida et al., 2009; Kotoda et al., 2010). Since MdTFL1-1 seems to be a flowering inhibitor, reduced expression in BS may serve as an internal clock to time inflorescence initiation in apple. Nevertheless, a similar reduction in MdTFL1-1 expression occurred in trees with HFL (Figure 4g). Using semiquantitative RT-PCR, others have reported an effect of fruit load on this gene's expression in apices of 1-year-old shoots (Kittikorn et al., 2011). Here, MdTFL1-1 levels decreased more rapidly in trees with HFL (Figure 4g); this difference could not explain why these BS apices remain vegetative.

This article is protected by copyright.All rights reserved. 


\section{Increased $M d T F L 1-2$ expression in BS apices adjacent to fruit}

In CFR at 0 DAFB trees, MdTFL1-2 was highly expressed in BS apices during anthesis. At other time points and in all other tissues examined, MdTFL1-2 expression was basal (Figure S7a). Using semi-quantitative RT-PCR, others have shown an expression pattern more similar to that of MdTFL1-1, albeit at lower levels (Mimida et al., 2009). However, in HFL trees preceding TII, transcripts of MdTFL1-2 reaccumulated in BS apices (Figures $4 \mathrm{~h}, \mathrm{i}$ and S7b). The first date on which expression was significantly higher in trees with fruit compared to trees without fruit varied slightly between sampling years (Figure 4h,i); nevertheless, this striking reaccumulation of MdTFL1-2 in HFL BS apices was consistent over 3 years of sampling (Figures 2b,d and 4h,i). By 94 DAFB, MdTFL1-2 levels in BS apices of HFL trees were up to 80-fold higher than those in BS apices of CFR at 0 DAFB trees (Figure 2b).

\section{MdTFL1-2 accumulation in spurs without fruit}

The presence of fruit inhibits inflorescence initiation in adjacent BS apices and increases MdTFL1-2 levels in those apices before TII. The two responses could be independent or connected: a fruit-load-dependent increase in MdTFL1-2 in BS apices toward TII might determine the vegetative fate of those meristems. We looked for cases in which prevention of inflorescence initiation occurs in the absence of adjacent fruit, and asked if in those cases, MdTFL1-2 accumulation also precedes TII.

As already noted, inflorescence initiation was not inhibited when fruitlets were removed at 0 or 36 DAFB. On the other hand, fruitlet removal at 80 DAFB was too late to allow complete inflorescence initiation (Figure 2a), suggesting that at this time point, the vegetative fate of the meristem carrying adjacent fruit was already partially determined. BS

This article is protected by copyright.All rights reserved. 
apices were sampled 94 DAFB from trees in which fruit had been removed at the different time points. At 94 DAFB, only HFL trees carried fruit, but MdTFL1-2 levels in BS apices were also high in trees from which fruit had been removed at 80 DAFB (Figure 2b). Thus, MdTFL1-2 levels in BS apices were correlated with meristem fate, and not with concurrent fruit presence (Figure 2a,b).

Previous research (Luckwill, 1970; Li et al., 2003) has suggested that the fate of the BS apex also depends on the amount of developing fruit in neighboring spurs or in general, on overall fruit load per tree. We studied return flowering and MdTFL1-2 expression in BS apices without fruit in a tree with moderate fruit load. Forty pairs of neighboring spurs were marked; all fruitlets were removed from one of the spurs 8 DAFB, thus generating pairs of adjacent spurs: one with HFL and the other with no fruit. For the spurs in each pair that developed several fruit, return bloom was 4\% (Figure 2a), similar to a HFL tree (Figure 2a). For the spurs from which fruitlets were removed at 8 DAFB, return bloom reached $57 \%$ (Figure 2a). In the BS apices of the latter spurs at 94 DAFB, MdTFL1-2 expression was significantly higher than in spurs taken from trees in which all flowers/fruit had been removed at 0 DAFB (Figure 2b). Both expression and flowering results suggest that the fate of the BS apex depends heavily on conditions within the spur, i.e., presence/absence of adjacent fruit and on overall fruit load per tree.

Removing BS leaves at certain times before TII prevents flowering of spurs with no fruit (Harley et al., 1942). In trees with heavy flowering, localized CFR was performed at 0 DAFB in 160 spurs. In 20 of those spurs, leaves were removed from the BS apex at 49 DAFB. Return flowering was $18 \%$ in HFL spurs and $66 \%$ in spurs in which flowers were removed at 0 DAFB (Figure 2c). On the other hand, removing all leaves from the BS apex in spurs without fruit reduced return bloom from $66 \%$ to $1.8 \%$ (Figure $2 \mathrm{c}$ ). Leaf removal also caused a 13-fold increase in MdTFL1-2 levels in BS apices 62 DAFB, only 13 days after leaf 
removal (Figure 2d). In the absence of developing fruit, local leaf removal in a BS will cause an increase in MdTFL1-2 levels and prevent the floral transition.

Exogenous application of gibberellin (GA) inhibits flowering in apple (Guttridge, 1962). At 30 DAFB (2013) or 34 DAFB (2014), 200 ppm $\mathrm{GA}_{3}$ was sprayed on spurs with no fruit. Before GA treatment, localized CFR was performed at 22 DAFB in 2013 from trees with moderate flowering, or at 0 DAFB in 2014 from trees with heavy flowering. In the BS apex, the $\mathrm{GA}_{3}$ treatment caused a relatively rapid change in expression of GA-responsive genes shown to be involved in a negative feedback loop that maintains GA homeostasis (Yamaguchi, 2008): an increase in GA deactivation (GA2 OXIDASE; Figure 5a,b) together with a decrease in GA biosynthesis (GA20 OXIDASE; significant reduction in 2014, Figure $5 \mathrm{c}, \mathrm{d})$. The $\mathrm{GA}_{3}$ treatment seemed to have a long-term effect on the BS apex because it caused a significant increase in MdTFL1-2 levels at 90-94 DAFB (Figure 5e,f). In addition, this single application caused a reduction (albeit not significant) in flowering (Figure $5 \mathrm{~g}, \mathrm{~h}$ ).

Others have suggested that fruit load inhibits apple flowering through an increase in active GA levels (Bangerth, 2009). BS apices with or without fruit have different expression levels of the aforementioned GA-responsive genes. The presence of adjacent fruit caused a response similar to that of $\mathrm{GA}_{3}$ application: an increase in expression of a gene encoding GA2 OXIDASE (Figure 6a,b) and a decrease in expression of two genes encoding GA20 OXIDASE (Figure 6d,e,g,h). In some cases, the initial differences in these GA-responsive genes' expression between treatments occurred earlier than the detected differences in MdTFL1-2 (Figure 4h,I, Table S1). Thus, fruit load causes the accumulation of MdTFL1-2 in BS apices, but prior to this accumulation, other fruit-load-related changes in BS apices may be evident.

This article is protected by copyright.All rights reserved. 


\section{Genetic variation in response to different fruit loads}

The degree of alternate bearing differs among commercial apple cultivars (Atay et al., 2013). Some of this variation was measured using the parameters and treatments developed above in 'Top Red'. A similar effect of fruit load on the expression of MdTFL1-2 (Figure 4j) and the abovementioned GA metabolism genes (Figure 6c,f,i) was detected in cultivar 'Golden Delicious'.

A previous report on hand thinning of 'Fuji'/'M9' trees over a 5-year period showed that leaving one fruit per spur results in $37-64 \%$ return flowering on the spurs; leaving two fruits led to no flowering, whereas leaving no fruit led to $80-90 \%$ return flowering (Davis, 2002). When comparing 'Golden Delicious' and 'Top Red' trees in which all spurs were handthinned to leave one flower per spur, the expression of MdTFL1-2 in BS apices was intermediate to high in 'Top Red' (Figure 2b) and very low (similar to BS apices with no adjacent fruit) in 'Golden Delicious' (Figure 7b). Return flowering was $21 \%$ in 'Top Red' (Figure 2a) and much higher in 'Golden Delicious' (Figures 7a and S3b). This suggests that natural variation in the response to different levels of fruit load may be a result of differences in MdTFL1-2 accumulation rate in BS apices.

We further compared cultivar 'Granny Smith' to 'Top Red', this time studying the effect of localized complete or partial (leaving one or two fruitlets) flower/fruit removal from 120 spurs per tree. A change in the local number of fruitlets per inflorescence significantly affected both MdTFL1-2 levels and return bloom in both genotypes (Figure 7c,d). In all three treatments, MdTFL1-2 levels in BS apices were significantly lower in 'Granny Smith' than in

'Top Red' (Figure 7d), whereas percent return bloom was significantly higher in the former (Figure 7c). Variation in the MdTFL1-2 gene is probably not the cause for variation in 
flowering response to different fruit loads, since we did not identify any linkage between a particular MdTFL1-2 allele and regular bearing (Table S2, Figure S10, Data S2, S3).

\section{DISCUSSION}

Alternate bearing in apple has been studied for at least 170 years (Cole, 1849; Butler, 1917), as it is a major constraint on fruit production. Links revealed here between fruit load, MdTFL1-2 accumulation and delay of flowering offer a new working model for the study of this phenomenon (Figure S8).

Recent research in mango, citrus (Citrus reticulata) and avocado (Persea americana) has suggested that fruit load prevents flowering in the following year by inhibiting the expression of FT-encoding genes in leaves, stems or buds (Muñoz-Fambuena et al., 2012; Nakagawa et al., 2012; Nishikawa et al., 2012; Shalom et al., 2012; Ziv et al., 2014). In these non-deciduous species, transcripts of FT-encoding genes accumulate during the winter, likely in response to cold temperatures (Nakagawa et al., 2012), before the initiation of inflorescences. In mango trees with previous HFL, FT expression was at least eightfold lower (Nakagawa et al., 2012).

In apple, as well as most other deciduous trees, the tree enters winter with buds containing flower primordia formed during the summer. These primordia will reach anthesis after winter dormancy, in the subsequent spring. Initial morphological changes in BS apices during the formation of the apple inflorescence (TII) are detected at 98-113 DAFB.

In our experiments, we did not identify any fruit load effect on the expression of the two FT-encoding genes, MdFT1 and MdFT2. Higher levels of MdFT1 expression were found in BS apices than in the leaf subtending the BS. In these apices, expression increased at least 6.5-fold from 14 to 83 DAFB, in trees with or without fruit. This initial increase, followed by a gradual decrease from the end of July until January, has been described previously (Kotoda 
et al., 2010). MdFT1 could be involved in shoot growth, similar to the FT-encoding gene described in poplar (Populus spp., Hsu et al., 2011). On the other hand, it could be necessary for flower induction, as it peaks before TII. A rise in MdFT2 expression in BS apices occurred in both treatments on the last sampling date, after TII. This pattern is similar to that described for MdFT2 in apical buds of fruit-bearing shoots (Kotoda et al., 2010). This increase in expression may be seasonal, occurring toward dormancy, and not related to flowering.

A gradual decline in MdTFL1-1 transcript levels from 0 to 68 DAFB (Figure 4g; Kotoda and Wada, 2005) may serve as the internal clock that determines TII in apples (Mimida et al., 2009; Flachowsky et al., 2012). A seasonal reduction in TFL1 was shown to control time of flowering in rose and strawberry (Iwata et al., 2012; Koskela et al., 2012). Using semi-quantitative RT-PCR, others noticed an effect of fruit load on this gene's expression in apices of 1-year-old shoots at one time point (Kittikorn et al., 2011). However, this effect was not observed here in BS apices, where many time points were sampled over several years using a more sensitive quantitative assay.

Similar to MdTFL1-1, expression of MdTFL1-2 in BS apices is high at anthesis, and then declines. While MdTFL1-1 expression remains low toward TII and is unaffected by fruit load, we show that MdTFL1-2 transcripts may reaccumulate in BS apices. Our experiments suggest that there are at least two major fruit-related parameters determining the fate of a specific BS apex: the number of fruit developing on the spur and the overall fruit load per tree. Interestingly, the contribution of each of these parameters to the following year's flowering in apple can be estimated by measuring the reaccumulation of MdTFL1-2 in BS apices toward TII.

This article is protected by copyright.All rights reserved. 
This reaccumulation was also detected in the absence of fruit in the spur due to late fruit removal (80 DAFB), GA 3 application or BS leaf removal at 49 DAFB. Again, in all three cases, the effect on return flowering could be predicted by measuring MdTFL1-2 in BS apices before TII. A strong negative correlation (Figure 8), based on data from two different years using two different cultivars, was found between MdTFL1-2 levels at 90-94 DAFB and flowering the following spring.

Evidence that both TFL1-encoding apple genes are expressed in the meristem has been provided by RNA in-situ hybridization (Mimida et al., 2011). The ability of both apple proteins to inhibit flowering in Arabidopsis and complement the tfl1-1 mutation has been previously shown (Kotoda and Wada, 2005; Mimida et al., 2009). Meristems in transgenic apple trees in which both TFL1-encoding genes have been knocked down seem to lose all timing restrictions, forming floral meristems randomly and consistently (Kotoda et al., 2006; Sasaki et al., 2011; Flachowsky et al., 2012). In BS that reaccumulate MdTFL1-2, there does not seem to be any period during which expression of both TFL1-encoding genes is low. Thus, our working hypothesis is that fruit load prevents flowering through reaccumulation of MdTFL1-2 in BS apices (Figure S8).

However, the minute, one-flower "inflorescence" and low fruit production of MdTFL1 knockdowns prevent the use of these transgenic lines to study the effect of fruit load in the absence of both genes. Our results warrant studying the phenotype of apple trees in which only MdTFL1-2 is knocked down or out. Since both genes are expressed in juvenile tissue (Mimida et al., 2009), a tree with intact MdTFL1-1 may maintain a juvenile period (which could last several years) and inflorescence initiation could be restricted to once a year. Perhaps the only extraordinary phenotype would be high levels of flowering in BS apices from spurs with HFL. Even using new approaches, such as the CRISPR-Cas9 system, obtaining a flowering tree with this genotype will likely take several more years.

This article is protected by copyright. All rights reserved. 
Shading apple trees (Auchter et al., 1926) or removing BS leaves at certain times before TII (Harley et al., 1942; Figure 2c) will prevent flowering of spurs with no fruit. Spur leaves begin to export carbohydrates within 10 days of growth onset (Hansen, 1977). Perhaps photosynthetically active leaves export a negative regulator of MdTFL1-2 expression to the BS apex. This might explain why MdTFL1-2 transcript levels in BS apices are relatively high at 0 DAFB and decrease thereafter, and why leaf removal at 49 DAFB caused an increase in MdTFL1-2 levels. This putative leaf-derived negative regulator of MdTFL1-2 expression might be a carbohydrate. There is some evidence that an artificial increase in sugars increases flowering in apple (Lakso, 1994).

Exogenous application of GA can inhibit flowering in apple (Guttridge, 1962; Marcelle and Sironval, 1963; Tromp, 1982). Here, inhibition of flowering caused by exogenous application of $\mathrm{GA}_{3}$ was relatively weak, perhaps because it was provided as a single application to specific spurs. Fruit load and exogenous application of $\mathrm{GA}_{3}$ had a similar effect on expression of certain genes encoding GA2 OXIDASE, GA20 OXIDASE and MdTFL1-2, and on inhibition of return flowering. Significant changes in MdTFL1-2 levels were mostly detected after changes in the GA-related genes. Clearly, changes in MdTFL1-2 levels are not the first response to the above perturbations. Inhibition of Apple flowering by application of exogenous GA might require changes in expression of other/additional genes.

GA inhibition of rose flowering appears to be mediated by induction of a TFL1encoding gene (Randoux et al., 2012), and this might also be the mode of GA inhibition of flowering in apple. The observed differences in GA-related gene expression in resposne to fruit load do not necessarly indicate whether there is more, less or the same amount of active 
GA in BS apices of HFL spurs. Although the observed changes should lead to a lower amount of active GA in these apices, they could be a result of higher levels of active GA in these apices triggering a negative feedback loop aimed at maintaining GA homeostasis (Yamaguchi, 2008). A popular model of alternate bearing suggests that seed-derived GAs are the transmissible signal that causes flower inhibition (Luckwill, 1970). Our findings cannot refute or support such a model. If active GAs are indeed accumulating in the BS apices of HFL spurs (as suggested by others), this accumulation might contribute to reaccumulation of MdTFL1-2 levels.

The amplitude of alternate bearing (variance in annual yield) differs among apple cultivars (Lauri et al., 1995). Annual yield is affected by additional parameters, such as natural and chemical flower/fruitlet thinning, percentage of bud release from dormancy, number of flowering spurs per tree and fruit size. Our comparison of cultivars was not based on variance in annual yield, but on how a BS apex responds to different numbers of adjacent fruit on the spur, or to overall fruit load per tree. In all three cultivars, an increasing number of fruit on the spur gradually decreased the chances of the BS apex entering the floral transition. While two or more fruit led to a non-flowering fate in 'Top Red' and 'Golden Delicious', some BS apices in 'Granny Smith' still flowered when spurs contained two developing fruit. Indeed 'Granny Smith' is less alternate bearing, based on variance in annual yield (Atay et al., 2013). In practice, to achieve consistent yields in 'Top Red', flowering/fruiting needs to occur in alternate spurs every year, since a spur with even one fruit has a very low chance of return bloom. In 'Golden Delicious', keeping a single fruit appears to be sufficient for return bloom, and therefore a strong thinning program that leaves no more than one fruit per spur should be enough to provide consistent fruit yields.

This article is protected by copyright.All rights reserved. 
For all fruit amounts (none, one, two), each genotype responded differently with respect to both MdTFL1-2 reaccumulation and return flowering. When comparing 'Top Red' and 'Granny Smith', the presence of additional fruit increased MdTFL1-2 levels in both genotypes, but levels in 'Top Red' were always higher, matching the lower rate of return bloom. This suggests that the two cultivars do not differ in their response to a certain level of MdTFL1-2, but may differ in the level of transcript accumulated. Interestingly, the effect of each additional fruit was not stronger in 'Top Red'. Local removal of all fruit from the spur led to significantly higher levels of MdTFL1-2 in BS apices of 'Top Red' compared to 'Granny Smith' at 90 DAFB. Thus, differences in basal (with no adjacent fruit) reaccumulation of MdTFL1-2 in BS apices might explain the different flowering behaviors of these two cultivars. Since this was a local treatment and not uniform removal of all fruitlets from the tree, the difference in basal reaccumulation of MdTFL1-2 levels may be due to unmeasured differences in overall fruit load per tree. If overall fruit load per tree was similar, the two cultivars may differ in their local interpretation of this parameter. Such a difference is not likely to be caused by a unique MdTFL1-2 allele. We did not find any MdTFL1-2 allele linked to regular bearing. In addition, previously identified QTLs that seem to affect the degree of alternate bearing in apple map to regions that do not contain the two TFL1encoding genes (Guitton et al., 2012).

In summary, variations in alternate bearing amplitude among cultivars may be a result of differences in MdTFL1-2 reaccumulation in response to different fruit loads or in basal levels of MdTFL1-2 in apices. Identifying alleles of genes that cause of these differences will likely help guide breeding programs. The knowledge obtained here regarding the response of the cultivars studied may already help improve their performance, by tailoring specific thinning procedures.

This article is protected by copyright. All rights reserved. 


\section{EXPERIMENTAL PROCEDURES}

\section{Plant material and treatment}

The experiments were conducted over three different years $(2011,2013$ and 2014) in a commercial apple orchard, planted in 1997, at the 'Matityahu' research station of the Agricultural Research Organization (ARO) in Northern Israel $\left(33^{\circ} 04^{\prime} 04^{\prime \prime N}, 35^{\circ} 27^{\prime} 04^{\prime \prime E}\right.$, altitude $667 \mathrm{~m}$ ). We studied 'Top Red' (a clone of 'Red Delicious') grafted on rootstock 'M9' over three seasons $(2011,2013,2014)$, 'Golden Delicious', also on 'M9' during two seasons (2013 and 2014), and ' Granny Smith' grafted on 'Hashabi 13-4' (local rootstock) during 2014. All trees were grown and pruned according to commercial practice. A list of experiments is provided in Table S3.

Trees in the different experiments were selected in the spring based on level of flowering. For most experiments, selected trees were with relatively high and uniform flowering (800-1000 spurs with inflorescences). Flowers/fruitlets were not hand or chemically thinned, unless this was the specific treatment. DAFB, specific to the orchard conditions, cultivar and year, was determined as the day with the highest number of flowers at anthesis: for 'Top Red' it was 27, 14 and 8 April in 2011, 2013 and 2014, respectively; for 'Golden Delicious', 8 April 2013, and for 'Granny Smith', 8 April 2014.

At full bloom (0 DAFB), 36 or 80 DAFB, all flowers/fruitlets were removed (CFR) from five trees on each date (five biological repeats). Following the removal, 100 spurs from which flowers/fruitlets were removed were selected from each tree and marked for RNA sampling or measurement of percent flowering spurs the following spring. The same number of similar types of spurs was selected from five additional trees in which no flowers or fruitlets were removed (HFL), each containing at least two fruits until harvest. In five 
additional trees, all inflorescences were hand-thinned, leaving one flower (preferably the terminal 'king' flower), so that each fruit-bearing spur contained a single fruit. All treatments were performed on 'Top Red', and CFR, HFL and single-fruit treatment were also performed on 'Golden Delicious'.

In five additional 'Top Red' trees, chosen for moderate flowering ( $~ 500-800$ spurs with inflorescences), 40 pairs of neighboring spurs, randomly distributed in the tree, were selected. All fruitlets were removed 8 DAFB from one of the spurs in the pair (localized CFR 8; spur without fruit), leaving the neighboring spur with at least two fruits (HFL).

In four 'Top Red' and four 'Granny Smith' trees chosen in 2014 for a similar high rate of flowering, 120 flowering spurs were selected and marked at 0 DAFB. At 26 DAFB, fruitlets in the selected spurs were randomly thinned to maintain either two, one or no fruit (40 spurs per treatment).

The flower/fruit were removed by cutting the pedicel/fruit stalk with secateurs. Chemical thinning is described in Figure S3b.

\section{Leaf removal}

In 2014, in five 'Top Red' trees chosen for high flowering rate, all flowers were removed from 160 spurs at full bloom (localized CFR 0). From these spurs, 20 were randomly selected and at $49 \mathrm{DAFB}$, all leaves from the axis of the BS were removed, by cutting the petioles with secateurs.

This article is protected by copyright. All rights reserved. 


\section{Tissue sampling}

Four spurs were sampled from each tree at every time point from spring until autumn. Three different tissues from these spurs were collected: the leaf that subtends the BS (designated spur leaf), the second-most mature leaf of the developing BS (BS leaf), and the BS apex from which all true leaves were removed (scales and primordial leaves intact; see Figure 1d,e).

\section{Flowering measurements}

Following spring/summer treatments, the effect on flowering was determined the following spring, at full bloom. Previously marked spurs in trees (9-28 per treatment) were examined and scored as either flowering (containing an inflorescence) or vegetative (producing only leaves), and percent flowering spurs was calculated. Rate of flowering was also scored at the tree level by visual assessment. Each tree was given a flowering score on a scale of $0-5$, ' 5 ' representing the highest flowering volume.

\section{Application of GA}

In the 2013 experiment, six 'Top Red' trees with moderate bloom ( 300-500 spurs with inflorescences) were chosen and 22 DAFB, all fruitlets were removed from 40 spurs per tree. In three trees, these spurs were sprayed with $200 \mathrm{ppm} \mathrm{GA}_{3}$ and $0.025 \%(\mathrm{v} / \mathrm{v})$ of the surfactant Triton X-100 (Sigma) on 30 DAFB. In the three remaining trees, these spurs were sprayed with surfactant only. In the 2014 experiment, 'Top Red' trees with a high rate of flowering were chosen and in each tree, on 0 DAFB, all fruitlets were locally removed from 160 spurs (localized CFR 0). In five trees, 50 of these spurs were sprayed with $\mathrm{GA}_{3}$ solution on 34 
DAFB. Five additional trees were not sprayed (control). $\mathrm{GA}_{3}(200 \mathrm{ppm})$ was prepared by adding $0.5 \mathrm{ml}$ of the commercial product 'Giberlon' (40,000 ppm; Fine Agrochemicals Ltd., Worcester, England) to $100 \mathrm{ml}$ water. Spurs were sprayed at around noon with a hand-held sprayer until they were drenched.

\section{Statistical analysis}

Data from qPCR results, and flowering were analyzed by one-way analysis of variance (ANOVA) using JMP version 10 software (SAS Institute, Cary, NC, USA). Differences between treatments were determined by Student's $t$ test. In multiple comparisons, Tukey-Kramer HSD was implemented. Statistical significance was determined at $P \leq 0.05$. In cases where the variance was unequal and the data did not show a normal distribution, the statistical tests were conducted on transformation to ranks of the values.

\section{SEM, RNA extraction, expression analysis and allele sequencing}

See Methods S1, in which there is reference to Figure S9, Tables S4 and S5 and Data S1.

\section{ACKNOWLEDGEMENTS}

This research was supported by the Israeli Science Foundation - the Charles H. Revson Foundation (grant no. 1464/07), the Chief Scientist of the Ministry of Agriculture and Rural 
Development, Israel (grant no. 458-0576-12), and the German-Israeli Project Cooperation (DIP project H 3.1). We would like to thank Yuval Ogni from the Matityahu research station, Paulo Stahl and Ein-Bar Rubinstein for technical help, and Hillary Voet for assistance with the statistical analyses.

\section{Short legends for Supporting Information}

Figure S1. Schematic representation of BS development in the spur branch of 'Top Red' during two years of alternate bearing.

Figure S2. Inflorescence development in 'Top Red' based on SEM images of BS apices sampled from June to October.

Figure S3. Flowering in response to different treatments of fruit load.

Figure S4. Expression of MdFT1 in three different tissues and under two levels of fruit load during the summer of 2011.

Figure S5. Expression of MdFT2 in three different tissues and under two levels of fruit load during the summers of 2011 and 2013.

Figure S6. Expression of MdTFL1-1 in three different tissues and under two levels of fruit load during the summer of 2011.

Figure S7. Expression of MdTFL1-2 in three different tissues and under two levels of fruit load during the summer of 2011.

Figure S8. Model describing the interactions between gene expression, flower induction and fruit load.

This article is protected by copyright.All rights reserved. 
Figure S9. Expression of MdTFL1-2 in BS apices from HFL trees, measured relative to histone 3 or actin 7.

Figure S10. Alignment of different MdTFL1-2 alleles.

Table S1. Timing of molecular events in different treatments.

Table S2. MdTFL1-2 alleles and bearing habits of different cultivars.

Table S3. List of the different treatments.

Table S4. List of primers for cloning, qPCR and allele sequencing.

Table S5. Testing primer specificity for the two AP1-encoding genes.

Data S1. Sequences of genes analyzed and primer positions

Data S2. Sequences of MdTFL1-2 alleles.

Data S3. Positions of Polymorphism between MdTFL1-2 alleles

Methods S1. Additional experimental procedures.

\section{REFERENCES}

Andres, F. and Coupland, G. (2012) The genetic basis of flowering responses to seasonal cues. Nat. Rev.Genet. 13, 627-639.

Atay, A.N., Koyuncu, F. and Atay, E. (2013) Relative susceptibility of selected apple cultivars to alternate bearing. J. Biol. Environ. Sci. 7, 81-86.

Auchter, E.C. and Schrader, A.L. (1923) Fruit spur growth and fruit bud production in the apple. J. Am. Soc. Hort. Sci. 20, 127-144.

This article is protected by copyright.All rights reserved. 
Auchter, E.C., Schrader, A.L., Lagasse, F.S. and Aldrich, W.W. (1926) The effect of shade on the growth, fruit bud formation and chemical composition of apple trees. Proc. Am. Soc. Hortic. Sci. 23, 368-382.

Bangerth, K.F. (2009) Floral induction in mature, perennial angiosperm fruit trees: Similarities and discrepancies with annual/biennial plants and the involvement of plant hormones. Sci. Hort. 122, 153-163.

Bergonzi, S. and Albani, M.C (2011) Reproductive competence from an annual and a perennial perspective. J. Exp. Bot. 62, 4415-4422.

Bradley, D., Carpenter, R., Copsey, L., Vincent, C., Rothstein, S. and Coen, E. (1996) Control of inflorescence architecture in Antirrhinum. Nature, 379, 791-797.

Bradley, D., Ratcliffe, O., Vincent, C., Carpenter, R. and Coen, E. (1997) Inflorescence commitment and architecture in Arabidopsis. Science, 275, 80-83.

Butler, O. (1917) On the cause of alternate bearing in the apple. Bull. Torrey Bot. Club, 44, 85-96.

Celton, J.M., Dheilly, E., Guillou, M.C., Simonneau, F., Juchaux, M., Costes, E., Laurens, F. and Renou, J.P. (2014) Additional amphivasal bundles in pedicel pith exacerbate central fruit dominance and induce self-thinning of lateral fruitlets in apple. Plant Physiol. 164, 1930-1951.

Cole, S.W. (1849) The Apple. In The American Fruit Book (Cole, S.W. ed). Boston, John P. Jewett, pp. 81-140.

Corbesier, L., Vincent, C., Jang, S., Fornara, F., Fan, Q., Searle, I., Giakountis, A., Farrona, S., Gissot, L., Turnbull, C. and Coupland, G. (2007) FT protein movement contributes to long-distance signaling in floral induction of arabidopsis. Science, 316, 1030-1033.

This article is protected by copyright.All rights reserved. 
Costes, E. (2003) Winter bud content according to position in 3-year-old branching systems of 'Granny Smith’ apple. Ann. Bot. 92, 581-588.

Davis, D.E. (2002) Inhibition of flower bud initiation and development in apple by defoliation, gibberellic acid and crop load manipulation. PhD Dissertation. Virginia Polytechnic Institute and State University.

Durand, J.B., Guitton, B., Peyhardi, J., Holtz, Y., Guedon, Y., Trottier, C. and Costes, E. (2013) New insights for estimating the genetic value of segregating apple progenies for irregular bearing during the first years of tree production. J. Exp. Bot. 64, 5099-5113.

Eccher, G., Botton, A., Dimauro, M., Boschetti, A., Ruperti, B. and Ramina, A. (2013) Early induction of apple fruitlet abscission is characterized by an increase of both isoprene emission and abscisic acid content. Plant Physiol. 161, 1952-1969.

Flachowsky, H., Szankowski, I., Waidmann, S., Peil, A., Traekner, C. and Hanke, M.V. (2012) The MdTFLl gene of apple (Malus $\times$ domestica Borkh.) reduces vegetative growth and generation time. Tree Physiol. 32, 1288-1301.

Forshey, C.G. and Elfving, D.C. (1989) The relationship between vegetative growth and fruiting in apple trees. In Horticultural Reviews, vol. 11 (Janick, J., ed). New York: John Wiley and Sons, Inc., pp. 229-287.

Foster, T., Johnston, R. and Seleznyova, A. (2003) A morphological and quantitative characterization of early floral development in apple (Malus $x$ domestica Borkh.). Ann. Bot. 92, 199-206.

Freiman, A., Shlizerman, L., Golobovitch, S., Yablovitz, Z., Korchinsky, R., Cohen, Y., Samach, A., Chevreau, E., Le Roux, P.-M., Patocchi, A. and Flaishman, M. (2012) Development of a transgenic early flowering pear (Pyrus communis L.)

This article is protected by copyright.All rights reserved. 
genotype by RNAi silencing of PcTFL1-1 and PcTFL1-2. Planta, 235, $1239-1251$.

Fulford, R.M. (1966) The morphogenesis of apple buds: iii. The inception of flowers. Ann. Bot. 30, 207-219.

Guitton, B., Kelner, J.-J., Velasco, R., Gardiner, S., Chagne, D. and Costes, E. (2012) Genetic control of biennial bearing in apple. J. Exp. Bot. 63, 131-149.

Guttridge, C.G. (1962) Inhibition of Fruit-bud formation in apples with gibberellic acid. Nature, 196, 1008.

Hansen, P. (1977) Carbohydrate allocation. In Environmental Effects on Crop Physiology (Landsberg, J.J. and Cutting, C.V., eds). London: Academic Press, pp. 247-258.

Harley, C.P., Masure, J.R. and Magness, J.R. (1935) Fruit thinning and biennial bearing on individual main leaders of Yellow Newtown apples. Proc. Am. Soc. Hort. Sci. 32, 43-46.

Harley, C.P., Magness, J.R., Masure, M.P., Fletcher, L.A. and Degman, E.S. (1942) Investigations on the cause and control of biennial bearing of apple trees. Technical Bulletin 792. Washington D.C.: United States Department of Agriculture, pp. 1-56.

Hattasch, C., Flachowsky, H., Kapturska, D. and Hanke, M.V. (2008) Isolation of flowering genes and seasonal changes in their transcript levels related to flower induction and initiation in apple (Malus domestica). Tree Physiol. 28, 1459-1466.

Higuchi, Y., Narumi, T., Oda, A., Nakano, Y., Sumitomo, K., Fukai, S. and Hisamatsu, T. (2013) The gated induction system of a systemic floral inhibitor, antiflorigen, 
determines obligate short-day flowering in chrysanthemums. Proc. Natl Acad. Sci. USA, 110, 17137-17142.

Hsu, C.-Y., Adams, J.P., Kim, H., No, K., Ma, C., Strauss, S.H., Drnevich, J., Vandervelde, L., Ellis, J.D., Rice, B.M., Wickett, N., Gunter, L.E., Tuskan, G.A., Brunner, A.M., Page, G.P., Barakat, A., Carlson, J.E., dePamphilis, C.W., Luthe, D.S. and Yuceer, C. (2011) FLOWERING LOCUS T duplication coordinates reproductive and vegetative growth in perennial poplar. Proc. Natl Acad. Sci. USA, 108, 10756-10761.

Iwata, H., Gaston, A., Remay, A., Thouroude, T., Jeauffre, J., Kawamura, K., Oyant, L.H.-S., Araki, T., Denoyes, B. and Foucher, F. (2012) The TFL1 homologue $\mathrm{KSN}$ is a regulator of continuous flowering in rose and strawberry. Plant J. 69, $116-125$.

Jonkers, H. (1979) Biennial bearing in apple and pear: a literature survey. Sci. Hort. 11, $303-317$.

Kardailsky, I., Shukla, V.K., Ahn, J.H., Dagenais, N., Christensen, S.K., Nguyen, J.T., Chory, J., Harrison, M.J. and Weigel, D. (1999) Activation tagging of the floral inducer FT. Science, 286, 1962-1965.

Kittikorn, M., Okawa, K., Ohara, H., Kotoda, N., Wada, M., Yokoyama, M., Ifuku, O., Yoshida, S. and Kondo, S. (2011) Effects of fruit load, shading, and 9,10-ketoloctadecadienoic acid (KODA) application on MdTFL1 and MdFT1 genes in apple buds. Plant Growth Regul. 64, 75-81.

Kobayashi, Y., Kaya, H., Goto, K., Iwabuchi, M. and Araki, T. (1999) A pair of related genes with antagonistic roles in mediating flowering signals. Science, 286, 1960-1962.

This article is protected by copyright.All rights reserved. 
Koskela, E.A., Mouhu, K., Albani, M.C., Kurokura, T., Rantanen, M., Sargent, D.J., Battey, N.H., Coupland, G., Elomaa, P. and Hytönen, T. (2012) Mutation in TERMINAL FLOWER1 reverses the photoperiodic requirement for flowering in the wild strawberry Fragaria vesca. Plant Physiol. 159, 1043-1054.

Kotoda, N. and Wada, M. (2005) MdTFL1, a TFL1-like gene of apple, retards the transition from the vegetative to reproductive phase in transgenic Arabidopsis. Plant Sci. 168, 95-104.

Kotoda, N., Iwanami, H., Takahashi, S. and Abe, K. (2006) Antisense expression of MdTFL1, a TFL1-like gene, reduces the juvenile phase in apple. J. Am. Soc. Hort. Sci. 131, 74-81.

Kotoda, N., Hayashi, H., Suzuki, M., Igarashi, M., Hatsuyama, Y., Kidou, S., Igasaki, T., Nishiguchi, M., Yano, K., Shimizu, T., Takahashi, S., Iwanami, H., Moriya, S. and Abe, K. (2010) Molecular characterization of FLOWERING LOCUS T-like genes of apple (Malus domestica Borkh.). Plant Cell Physiol. 51, 561-575.

Lakso, A.N. (1994) Apple. In Handbook of Environmental Physiology of Fruit Crops, Vol I: Temperate Crops (Schaffer, B. and Andersen, P.C., eds). Boca Raton, Florida: CRC Press, Inc., pp. 3-42.

Lang, A., Chailakhyan, M.K. and Frolova, I.A. (1977) Promotion and inhibition of flower formation in a dayneutral plant in grafts with a short-day plant and a longday plant. Proc. Natl Acad. Sci. USA, 74, 2412-2416.

Lauri, P.E., Terouanne, E., Lespinasse, J.M., Regnard, J.L. and Kelner, J.J. (1995) Genotypic differences in the axillary bud growth and fruiting pattern of apple fruiting branches over several years - an approach to regulation of fruit bearing. Sci. Hort. 64, 265-281.

This article is protected by copyright.All rights reserved. 
Li, K.T., Lakso, A.N., Piccioni, R. and Robinson, T. (2003) Summer pruning effects on fruit size, fruit quality, return bloom and fine root survival in apple trees. J. Hort. Sci. Biotechnol. 78, 755-761.

Lifschitz, E., Eviatar, T., Rozman, A., Shalit, A., Goldshmidt, A., Amsellem, Z., Alvarez, J.P. and Eshed, Y. (2006) The tomato FT ortholog triggers systemic signals that regulate growth and flowering and substitute for diverse environmental stimuli. Proc. Natl Acad. Sci. USA, 103, 6398-6403.

Luckwill, L.C. (1970) The control of growth and fruitfulness of apple trees. In Physiology of Tree Crops (Luckwill, L.C. and Cutting, C.V., eds). London: Academic Press, pp. 237-254.

Marcelle, R. and Sironval, C. (1963) Effect of Gibberellic Acid on Flowering of Apple Trees. Nature, 197, 405-405.

McLaughlin, J.M. and Greene, D.W. (1991) Fruit and hormones influence flowering of apple. 1. Effect of cultivar. J. Am. Soc. Hort. Sci. 116, 446-449.

Mehri, H. and Crabbe, J. (2002) Processus de développement génératif chez le pommier cv Golden Delicious. Biotechnol. Agr. Soc. Environ. 6, 51-60.

Mimida, N., Kotoda, N., Ueda, T., Igarashi, M., Hatsuyama, Y., Iwanami, H., Moriya, S. and Abe, K. (2009) Four TFL1/CEN-like genes on distinct linkage groups show different expression patterns to regulate vegetative and reproductive development in apple (Malus $\times$ domestica Borkh.). Plant Cell Physiol. 50, 394-412.

Mimida, N., Ureshino, A., Tanaka, N., Shigeta, N., Sato, N., Moriya-Tanaka, Y., Iwanami, H., Honda, C., Suzuki, A., Komori, S. and Wada, M. (2011) Expression patterns of several floral genes during flower initiation in the apical buds of apple (Malus $\times$ domestica Borkh.) revealed by in situ hybridization. Plant Cell Rep. 30, $1485-1492$.

This article is protected by copyright. All rights reserved. 
Monselise, S.P. and Goldschmidt, E.E. (1982) Alternate bearing in fruit trees. Hort. Rev. 4, 128-173.

Muñoz-Fambuena, N., Mesejo, C., González-Mas, M.C., Primo-Millo, E., Agustí, M. and Iglesias, D.J. (2012) Fruit load modulates flowering-related gene expression in buds of alternate-bearing 'Moncada' mandarin. Ann. Bot. 110, 1109-1118.

Nakagawa, M., Honsho, C., Kanzaki, S., Shimizu, K. and Utsunomiya, N. (2012) Isolation and expression analysis of FLOWERING LOCUS T-like and gibberellin metabolism genes in biennial-bearing mango trees. Sci. Hort. 139, $108-117$.

Nishikawa, F., Iwasaki, M., Fukamachi, H., Nonaka, K., Imai, A., Takishita, F., Yano, T. and Endo, T. (2012) Fruit bearing suppresses citrus FLOWERING LOCUS T expression in vegetative shoots of Satsuma mandarin (Citrus unshiu Marc.). J. Jap. Soc. Hort. Sci. 81, 48-53.

Putterill, J., Zhang, L., Yeoh, C.C., Balcerowicz, M., Jaudal, M. and Gasic, E.V. (2013) FT genes and regulation of flowering in the legume Medicago truncatula. Funct. Plant Biol. 40, 1199-1207.

Samach, A. and Smith, H.M. (2013) Constraints to obtaining consistent annual yields in perennials II: environment and fruit load affect flowering induction. Plant Sci. 207, 168-176.

Sasaki, S., Yamagishi, N. and Yoshikawa, N. (2011) Efficient virus-induced gene silencing in apple, pear and Japanese pear using Apple latent spherical virus vectors. Plant Methods, 7, 15.

Shalom, L., Samuels, S., Zur, N., Shlizerman, L., Zemach, H., Weissberg, M., Ophir, R., Blumwald, E. and Sadka, A. (2012) Alternate bearing in citrus: changes in the 
expression of flowering control genes and in global gene expression in on- versus off-crop trees. PLOS ONE, 7, e46930.

Shannon, S. and Meeks-Wagner, D.R. (1991) A mutation in the arabidopsis TFL1 gene affects inflorescence meristem development. Plant Cell, 3, 877-892.

Smith, H.M. and Samach, A. (2013) Constraints to obtaining consistent annual yields in perennials tree crops. I: Heavy fruit load dominates over vegetative growth. Plant Sci. 207, 158-167.

Tamaki, S., Matsuo, S., Wong, H.L., Yokoi, S. and Shimamoto, K. (2007) Hd3a protein is a mobile flowering signal in rice. Science, 316, 1033-1036.

Traekner, C., Lehmann, S., Hoenicka, H., Hanke, M.V., Fladung, M., Lenhardt, D., Dunemann, F., Gau, A., Schlangen, K., Malnoy, M. and Flachowsky, H. (2010) Over-expression of an FT-homologous gene of apple induces early flowering in annual and perennial plants. Planta, 232, 1309-1324.

Tromp, J. (1982) Flower-Bud Formation in Apple as Affected by Various Gibberellins. Journal of Horticultural Science, 57, 277-282.

Wilkie, J.D., Sedgley, M. and Olesen, T. (2008) Regulation of flower initiation in horticultural trees. J. Exp. Bot. 59, 3215-3228.

Yamagishi, N., Sasaki, S., Yamagata, K., Komori, S., Nagase, M., Wada, M., Yamamoto, T. and Yoshikawa, N. (2011) Promotion of flowering and reduction of a generation time in apple seedlings by ectopical expression of the Arabidopsis thaliana FT gene using the apple latent spherical virus vector. Plant Mol. Biol. 75, 193-204.

Yamaguchi, S. (2008) Gibberellin metabolism and its regulation. Annu. Rev. Plant Biol. 59, 225-251. 
Yao, J., Dong, Y. and Morris, B.A. (2001) Parthenocarpic apple fruit production conferred by transposon insertion mutations in a MADS-box transcription factor. Proc. Natl Acad. Sci. USA, 98, 1306-1311.

Ziv, D., Zviran, T., Zezak, O., Samach, A. and Irihimovitch, V. (2014) Expression profiling of FLOWERING LOCUS T-like gene in alternate bearing 'Hass' avocado trees suggests a role for PaFT in avocado flower induction. PLoS ONE, 9, e110613.

\section{Figure Legends}

\section{Figure 1.}

(a,b) Pictures of two adjacent 'Top Red' trees taken at the same date (April 27 2011), one with many flowers (a), the other with very few flowers (b).

(c) A spur with an inflorescence at full bloom; a BS with two to three open leaves can be seen.

(d) Spur with three developing fruit (one was removed) and a BS at 43 DAFB.

(e) Sketch of picture in (d). The BS apex will likely remain vegetative due to the presence of adjacent fruit. In the absence of fruit it may terminate with an inflorescence that will reach anthesis in the subsequent spring.

Figure 2. Flowering and MdTFL1-2 expression in BS apices in response to different treatments.

Experiments were performed in the summer of 2013 (a,b) and 2014 (c,d) on 'Top Red' trees (see Experimental Procedures). Trees with HFL were not thinned, and selected spurs contained at least two fruits. In OFL trees, all flowers clusters in the tree were thinned to one 
flower at 0 DAFB, containing one fruit until harvest. In CFR trees, all flowers/fruit on a tree were removed at full bloom (0 DAFB) or at 36 or 80 DAFB. 'Pairs of spurs' - pairs of proximate spurs were chosen, and in one spur from each pair, all fruitlets were removed at 8 DAFB (LCFR 8 spur), while its neighbor kept at least two fruit until harvest (HFL spur). In localized CFR 0 trees (c,d), all flowers were removed from 160 spurs per tree at 0 DAFB. In 20 of these spurs, all leaves from the axis of the BS were removed at 49 DAFB (LCFR 0, LR 49).

$(\mathrm{a}, \mathrm{c})$ Percentage of flowering spurs, as measured in the spring of the year following the treatment. Preselected spurs [ $\mathrm{n}=22$ in (a), $n=18$ in (c)] were scored for presence/absence of inflorescence.

(b,d) Relative expression of MdTFL1-2 in BS apices collected 94 (b) or 62 (d) DAFB for the same treatments and trees as in (a) and (c), respectively. Relative MdTFL1-2 expression was measured using quantitative real-time RT-PCR (qPCR) and the housekeeping histone 3encoding gene (see Methods S1). Numbers are mean values of five independent biological repeats (trees) \pm standard error of the mean (SE; bars).

Different letters represent significant differences according to Tukey-Kramer HSD test on ranked data $(P \leq 0.05)$.

Figure 3. BS apical meristems based on SEM images from 'Top Red'.

$(\mathrm{a}-\mathrm{c})$ Images of BS apices from trees in which all flowers were removed at full bloom (CFR 0): (a) meristem at $55 \mathrm{DAFB}$, apical meristem is still forming leaf primordia; (b) meristem at 113 DAFB, apical meristem is forming an inflorescence; (c) meristem at 152 DAFB, sepals of the terminal flower have initiated.

This article is protected by copyright.All rights reserved. 
(d) Image of a BS apex from a tree with HFL at 113 DAFB. Unlike the apex in (b), collected on the same date, this apex is still forming leaf primordia. Each image represents several samples examined for the specific treatment. Ap, apex; L, leaf; Tm, terminal flower meristem; B, bract; $\mathrm{Tb}$, terminal bract; Lm, lateral flower meristem; Bl, bractlet; S, sepal. Scale bar is $0.1 \mathrm{~mm}$.

Figure 4. Expression of flowering-related apple genes in BS apices from trees with or without developing fruit.

Heavy flowering trees were either untreated, thus reaching heavy fruit load (HFL), or all flowers were removed at full bloom (CFR 0). All experiments were with the 'Top Red' cultivar except (j), which was with 'Golden Delicious'. Samples were collected during the summer of 2011 (a,c,e,g,i) and 2013 (b,d,f,h,j).

Relative expression of MdAPla (a,b), MdAPIb (c,d), MdPI (e,f), MdTFL1-1 (g) and MdTFL1-2 (h-j), measured as described in Figure 2b. Numbers are mean values of three to five independent biological repeats (trees) \pm SE (bars). Asterisks represent a significant difference between treatments at a specific time point according to Student's $t$ test on ranked data $(P \leq 0.05)$.

Figure 5. Gene expression and flowering response of BS apices to $\mathrm{GA}_{3}$ application.

Experiments were performed in the summer of 2013 (a,c,e,g) and 2014 (b,d,f,h) on 'Top Red' trees. In each tree, flowers/fruitlets were removed from a number of spurs at a certain date (40 spurs on 22 DAFB, 2013, 160 spurs on 0 DAFB, 2014). In some trees the aforementioned spurs were sprayed with 200ppm $\mathrm{GA}_{3}$ and in others they were not (surfactant in 2013, no 
treatment in 2014). The single $\mathrm{GA}_{3}$ treatment was given on 30 DAFB (2013) or 34 DAFB (2014). Relative expression of MdGA2ox2b (a,b), MdGA20oxlc (c,d) and MdTFL1-2 (e,f) measured as described in Figure 2b. (g,h) Percentage of flowering spurs, as measured in spring, the following year of the treatment. Numbers are mean values of three (2013) or five (2014) independent biological repeats (trees) \pm SE (bars). Asterisks represent a significant difference between treatments at a specific time point according to Student's $t$ test on ranked data $(P \leq 0.05)$.

Figure 6. Expression of GA-related apple genes in BS apices from trees with or without developing fruit.

RNA samples are the same as those used in Figure 4. Relative expression of MdGA2ox2b (ac), MdGA20oxla (d-f) and MdGA20oxlc (g-i) measured as described in Figure 2b. Numbers are mean values of three to five independent biological repeats (trees) $\pm \mathrm{SE}$ (bars). Asterisks represent a significant difference between treatments at a specific time point according to Student's t test on ranked data $(P \leq 0.05)$.

Figure 7. Variation among cultivars in flowering and MdTFL1-2 expression in response to different fruit loads.

(a,b) Experiments with 'Golden Delicious' performed in the summer of 2013. Treatments were similar to those performed on 'Top Red' (Figure 2a,b). Different letters indicate a significant difference between treatments according to Student's $t$ test on ranked data $(P \leq$ 0.05). (a) Average score of flowering intensity per tree as estimated during bloom of the following year (2014). (b) Relative expression of MdTFL1-2 in BS apices collected 70 DAFB.

This article is protected by copyright. All rights reserved. 
(c,d) A comparison of 'Granny Smith' and 'Top Red' trees in response to different amounts of adjacent fruit on the spur. In each tree, 120 spurs were selected, and at 26 DAFB, fruitlets in the spurs were thinned to maintain two, one or no fruit. All comparisons between cultivars for a specific fruit load were found significantly different according to Student's t test $(P \leq 0.05)$. Different letters indicate a significant difference between treatments in the same cultivar according to Tukey-Kramer HSD test $(P \leq 0.05)$. (c) Percentage of flowering spurs calculated as in Figure 2a, based on 21 preselected spurs per treatment. (d) Relative expression of MdTFL1-2 in BS apices collected 90 DAFB, measured as described in Figure $2 b$.

Numbers are mean values of ten $(\mathrm{a})$, three $(\mathrm{b})$ or four $(\mathrm{c}, \mathrm{d})$ biological repeats (trees) $\pm \mathrm{SE}$ (bars).

Figure 8. Correlation between MdTFL1-2 relative expression in BS apices at $\sim 90$ DAFB and percentage of flowering spurs. Data are taken from Figure 2a,b and Figure 7c,d. Each dot represents a treatment's mean value of independent biological repeats (trees; $n=4-5$ ). Full dots represents data from 'Top Red' and empty dots are data from 'Granny Smith'. Adjusted $\mathrm{R}^{2}$ is 0.81 .

This article is protected by copyright.All rights reserved. 


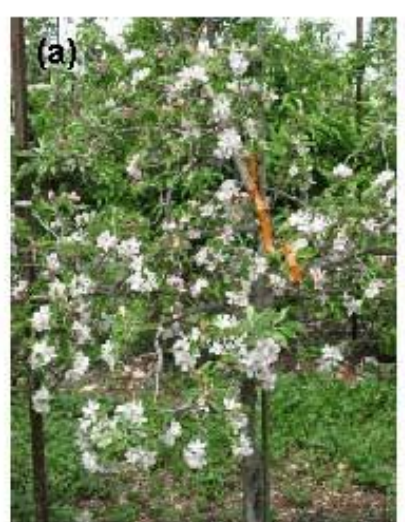

(d)

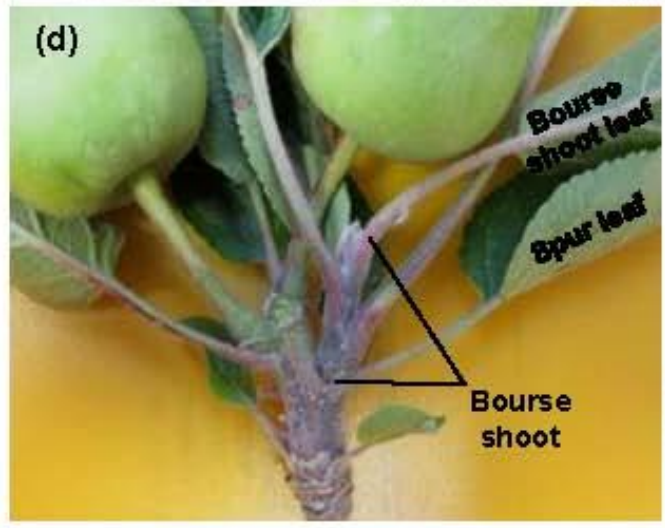

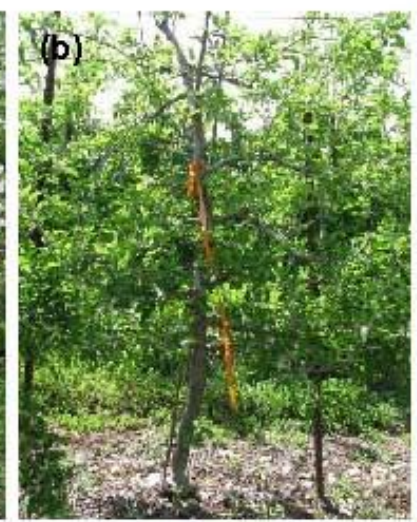
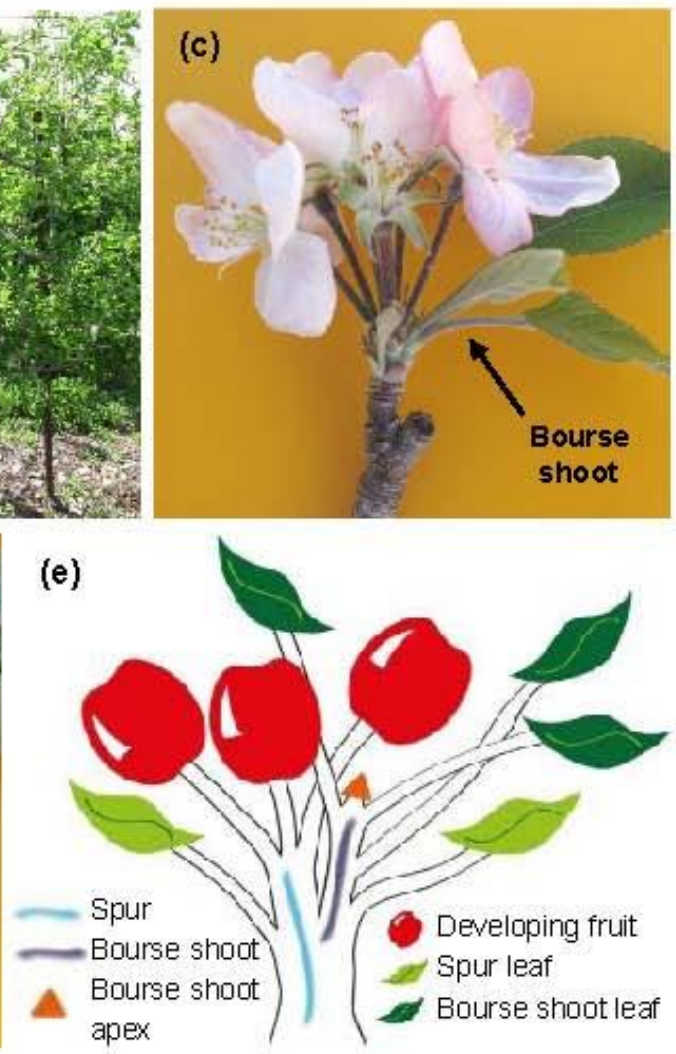

This article is protected by copyright.All rights reserved.

Haberman, A., Ackerman, M., Crane, O., Kelner, J.-J., Costes, E., Samach, A. (2016). Different flowering response to various fruit loads in apple cultivars correlates with degree of 

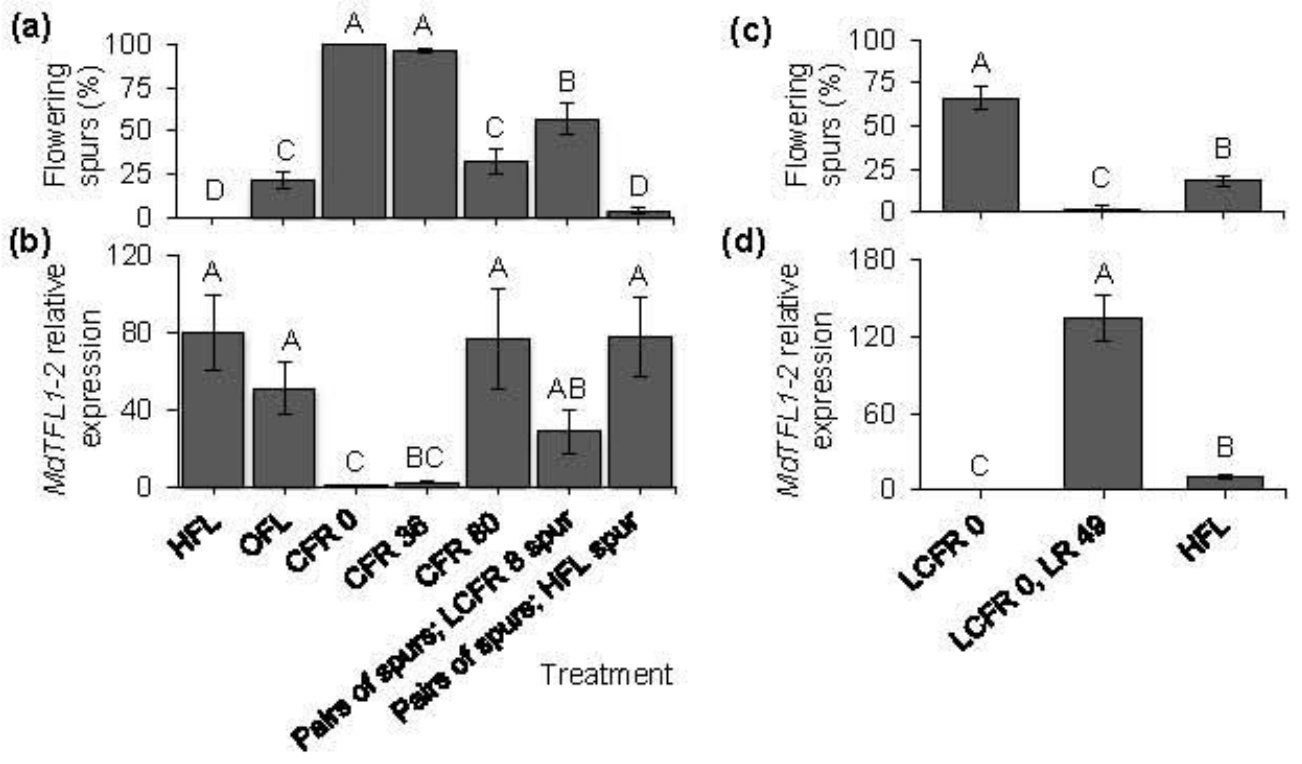

(d)

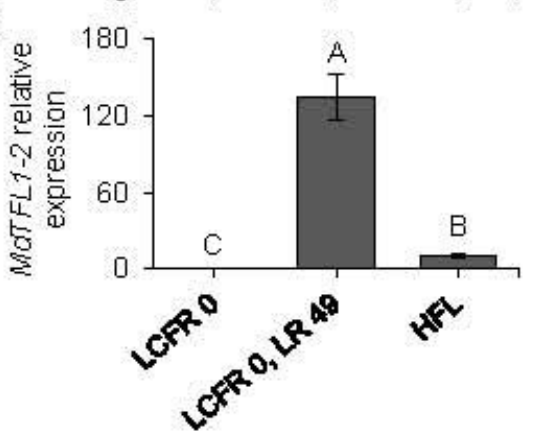

This article is protected by copyright All rights reserved. 

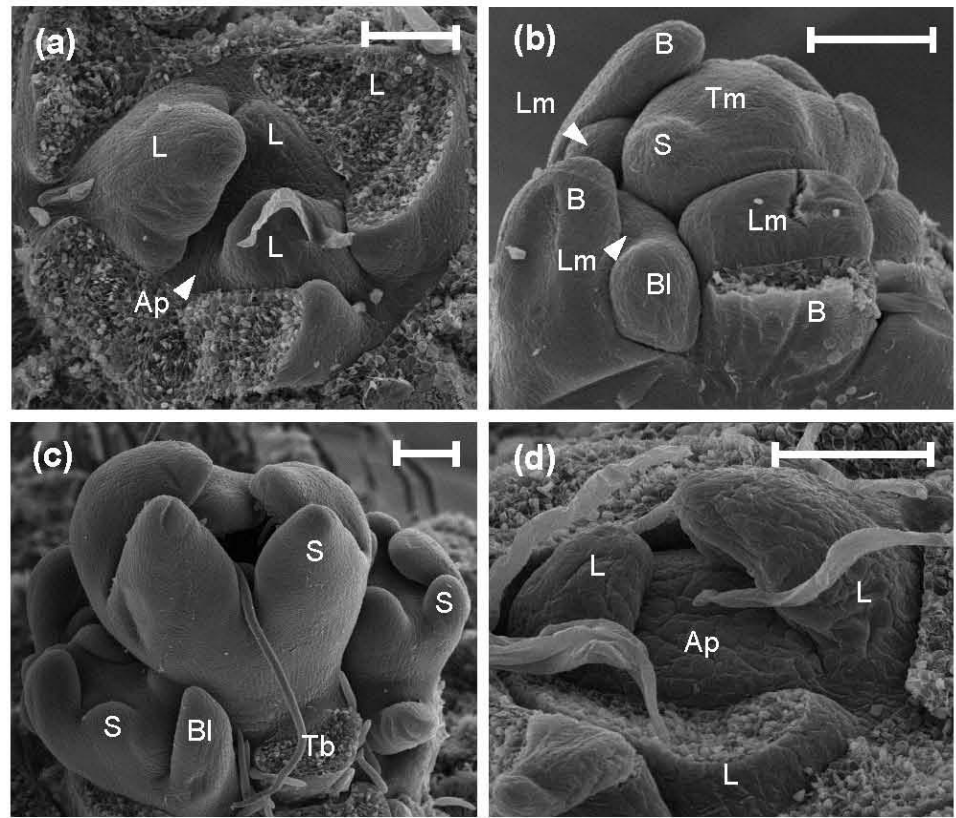

This article is protected by copyright.All rights reserved.

Haberman, A., Ackerman, M.. Crane, O.. Kelner. J.-J.. Costes, E., Samach, A. (2016). Different flowering response to various fruit loads in apple cultivars correlates with degree of 

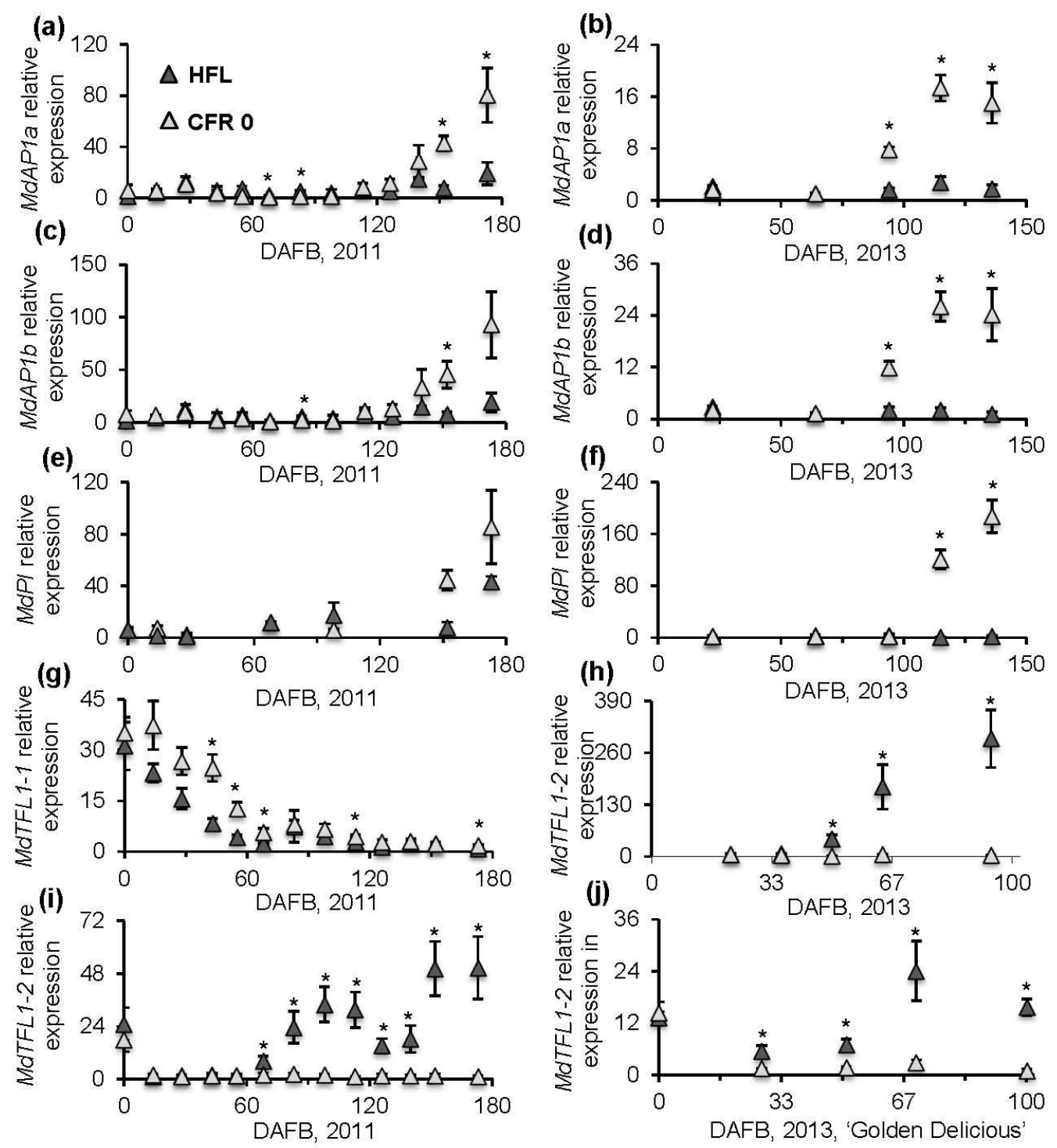

This article is protected by copyright All rights reserved. 
(a)

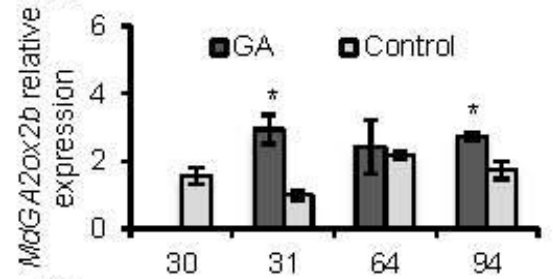

(c)

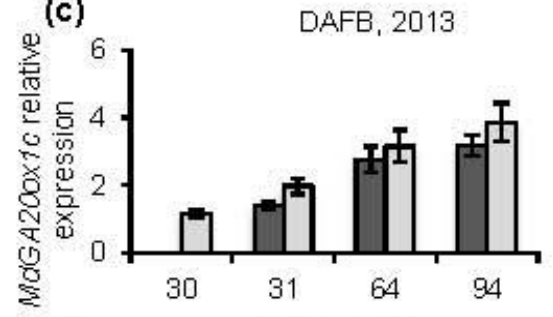

(e)

贾

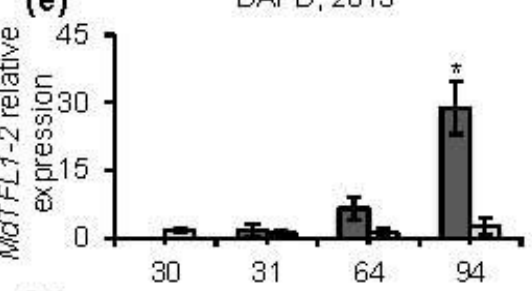

(g)

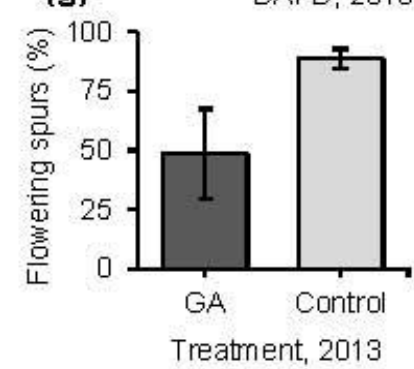

(b)

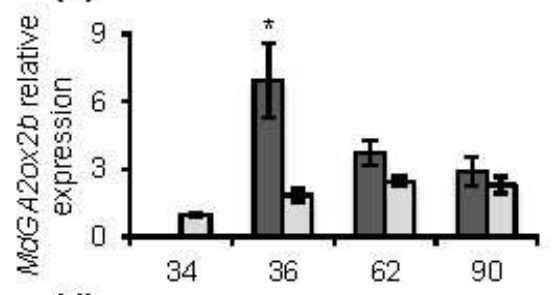

(d)
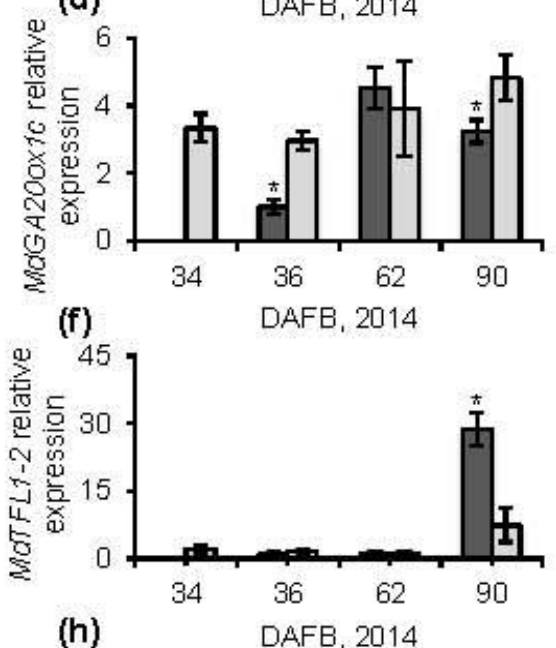

(h)

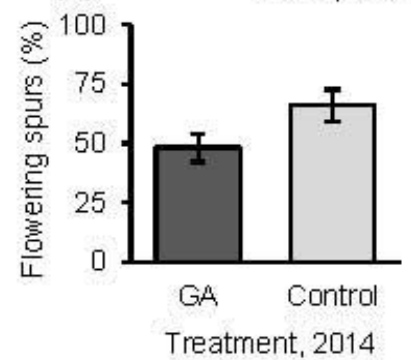

This article is protected by copyright.All rights reserved. 

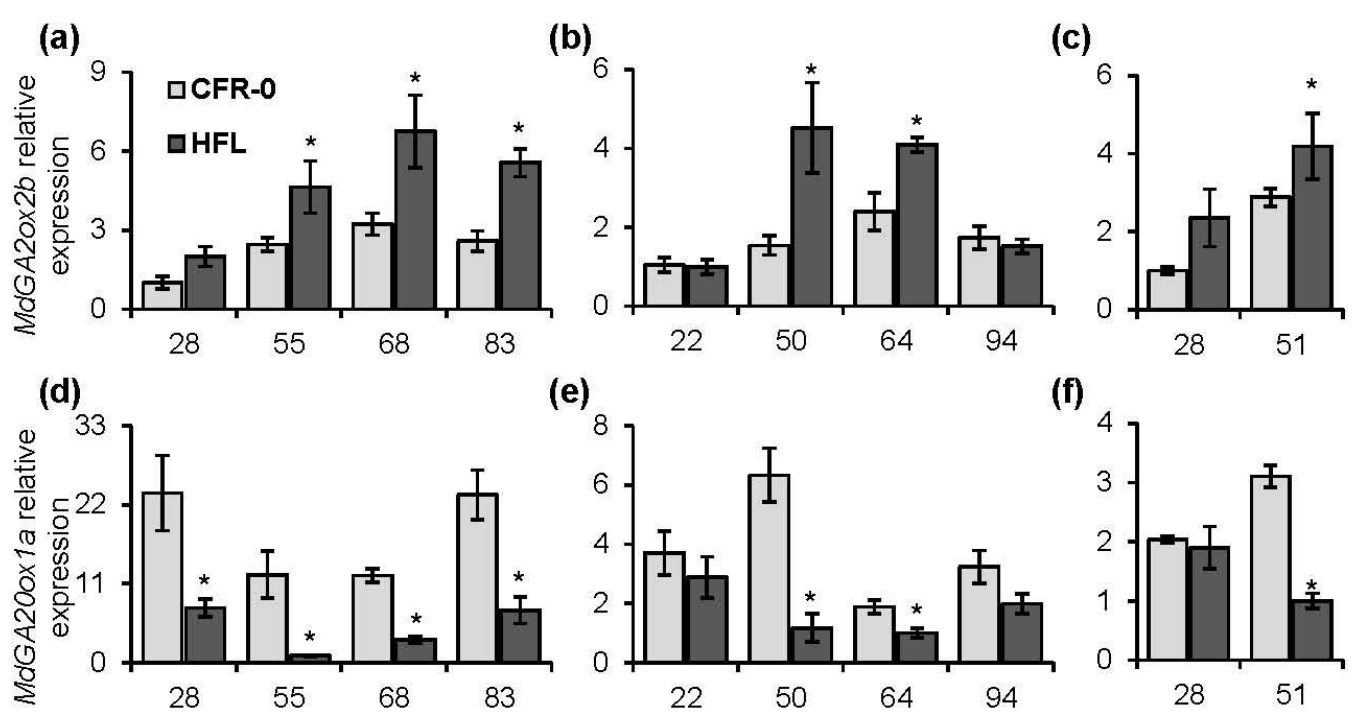

(g)

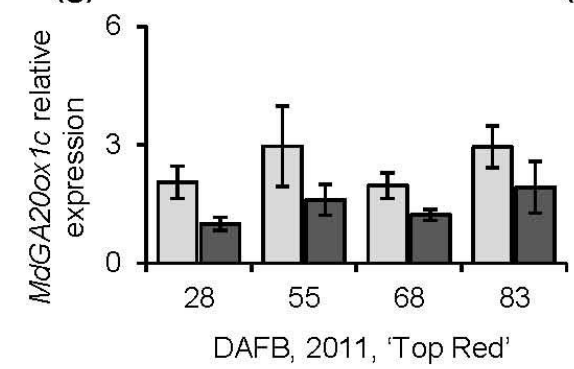

(e)

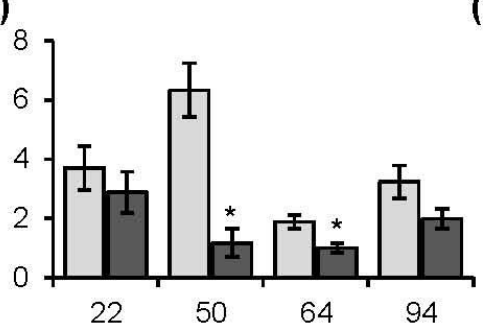

(f)

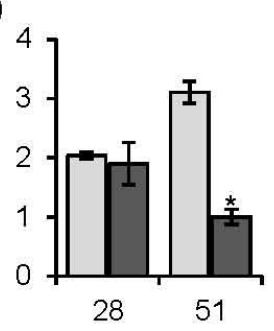

(i)
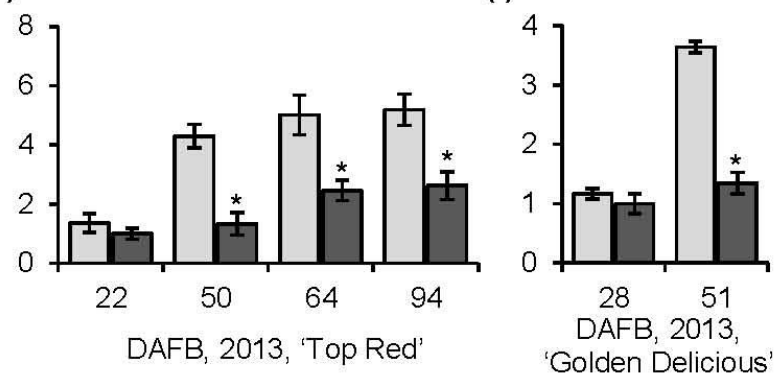

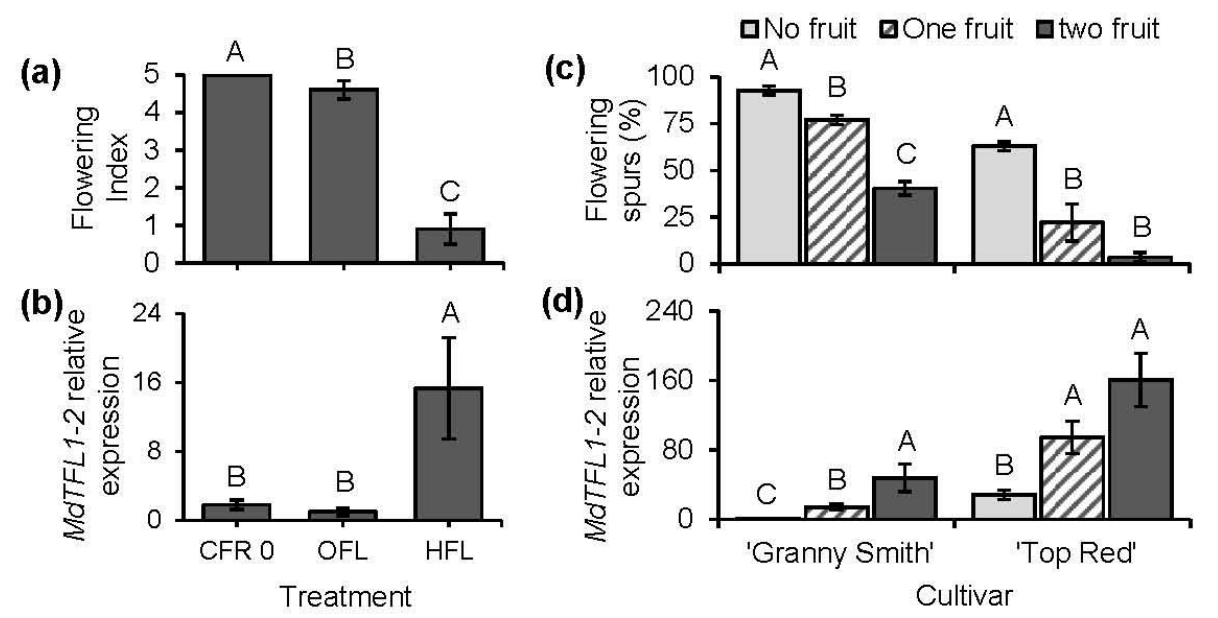

This article is protected by copyright All rights reserved. 


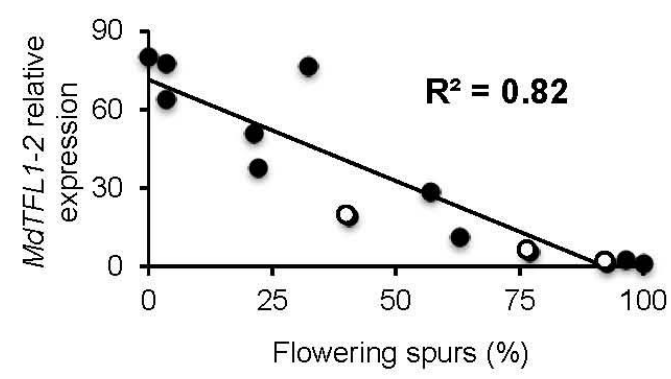

This article is protected by copyright All rights reserved.

Haberman, A., Ackerman, M., Crane, O.., Kelner, J.-J., Costes, E., Samach, A. (2016). Different flowering response to various fruit loads in apple cultivars correlates with degree of 